\title{
Choice, consumerism and devolution: growing old in the welfare state(s) of Scotland, Wales and England
}

\author{
SUZANNE MOFFATT*, PAUL HIGGS†, KIRSTEIN RUMMERY \\ and IAN REES JONES§
}

\begin{abstract}
The introduction of choice and consumer mechanisms in public services has been identified as a fundamental shift in welfare service provision internationally. Within the United Kingdom (UK), such mechanisms developed and integrated into English services have not been replicated in their entirety in Scotland and Wales. For the first time since the inception of the UK welfare state, there are now formal differences in entitlement for older people as a result of devolution. This paper uses comparative policy analysis to review a range of sources not hitherto brought together in order to explore how these concurrent developments - choice and devolution-impact on people over state retirement age. We also consider the extent to which a more consumerist approach to public services might redress or increase later-life inequalities. Drawing on theoretical research and policy evidence, we argue that for many people over state retirement age, the prospect of becoming a consumer in these varied contexts is difficult and unwelcome. We suggest that although it is too early in the devolutionary process for any significant impact of these divergent policies to materialise, continued policy divergence will lead to different experiences and outcomes for older people in Scotland, Wales and England. We conclude that these divergent social policies offer significant research opportunities, particularly concerning their impact on later-life inequalities.
\end{abstract}

KEY WORDS - choice and consumerism, UK devolution, welfare states, inequality.

\section{Introduction}

As developed welfare states across the world try to find ways of coping with the increasing demand for services for older people, there have been significant political and ideological changes in the welfare landscape in the

* Institute of Health \& Society, Newcastle University, Newcastle upon Tyne, UK.

$\dagger$ Department of Mental Health Sciences, University College London, London, UK.

* School of Applied Social Science, Stirling University, Stirling, UK.

$\S$ School of Social Sciences, Bangor University, Bangor, UK. 
United Kingdom (UK) that, in some cases, mirror international developments. The move towards choice and consumerism in public services has been identified as a fundamental shift in welfare service provision with particular significance in the neo-liberal mixed-market welfare regimes, but also increasingly in social democratic regimes which are also facing significant rising demand due to ageing populations (Clarke et al. 2007). Another part of the shifting landscape of welfare provision has been changes in the political governance of welfare, with increasing pressure on local and regional government levels to provide older people's welfare services in a residual or means-tested form that were previously seen as the remit of national government levels and provided more universally (Rummery 2009). Concurrent with these political and ideological developments, many developed welfare states are looking to decentralise welfare provision and devolving powers to regional and local assemblies more generally, which arguably offers opportunities for more locally responsive, cost-effective services and for policy learning and transfer to take place across regions and local government levels (Williams and Mooney 2008). Conversely, increasing regionalisation and devolution also offers scope for an undermining of social citizenship and of increasing inequities in welfare across regions (Jeffery 2008).

This paper seeks to explore the impact of these two concurrent developments on people over state retirement age in Scotland, Wales and England for three main reasons. First, they are the age group most likely to make use of public services; second, they have had the longest immersion in the post-war consensus 'cradle to grave' discourse of the post-1945 (or Beveridge-inspired) welfare state; and third, they are most likely to have corresponding expectations about the responsibilities of the welfare state, having grown up in the decades following the establishment of a social compact, one part of which was social entitlement in contrast to the individual responsibilities of the 'citizen-consumer'. Since the 1970s, the welfare state has undergone a sustained period of retrenchment (Taylor-Gooby 2000, 2001). The mechanisms which formerly articulated a desire to provide security in later life now focus on contingency and old age is increasingly seen as an individual responsibility with many different possible outcomes (Phillipson 2002; Gilleard and Higgs 2005).

The aims of this paper are to consider the possible impacts of these changes on older people who were the early beneficiaries of the universalist approach to health and social security, but who must now adjust to a markedly different approach to health and social care provision, pensions and social security. The introduction and extension of consumerism and individualism in welfare provision is a marked feature of neo-liberal welfare states (Esping Andersen 1996) but both the discourse of consumerism and 
choice, and the way in which it impacts on welfare provision for older people, have become a dominant feature of all developed welfare states. Primarily, we are concerned with examining lessons from our case study of policy devolution in the UK to see whether a more consumerist approach to public service provision is likely to redress or reinforce existing later-life inequalities, particularly in welfare states which have adopted or extended such approaches. Comparative policy analysis is usually carried out across different welfare states, drawing up typologies and dependent and independent variables to examine patterns of policy development, implementation and outcomes (Clasen 1998). In this paper, we will be using the method of comparative policy analysis to examine how policy developments have converged and diversified following the impact of devolution in UK social policy. In doing so, our purpose is to compare current welfare provision in each case with alternatives drawn from the comparative cases as a way of evaluating policies with regards to outcomes for older people (Hill 2006). We do this by bringing together material from an array of sources, not hitherto brought together, to explore whether and how older people appear to be adapting to the shift towards choice and consumerism in public services in the different contexts under examination. Bearing in mind the importance of context in our analysis, we take account of the impact of UK devolution which has resulted in variation in the extent to which choice and consumer values and mechanisms pervade public services. Drawing on an analysis of the discourse of policy rhetoric and the impact of specific policy outcomes, we offer a critical analysis of the impact on older people of the increased emphasis on choice in public services, against the backdrop of devolutionary changes that increase policy variation across the UK. We then draw out the lessons from our specific case studies that might be applicable more widely in the context of policy development framed by what we find to be the increasing hegemony of 'choice' and 'consumerism' with regards to how people experience ageing in the different policy and welfare domains of Scotland, England and Wales.

\section{Theorising older people's relations with the choice agenda and public services}

Choice and consumerism have become a dominant policy discourse across welfare states, not only in the liberal models epitomised by the UK (and similar mixed-market regimes such as the United States of America, Canada and Australia), but also in social-democratic/universalist models such as Sweden and Denmark (Blomqvist 2004; Greve 2009). Choice is often presented as a hegemonic positive response to active participation in the 
provision and delivery of welfare, with one health-care commentator arguing persuasively that no-one could, 'argue against the desirability of allowing patients more say in decisions concerning them' (Appleby, Harrison and Devlin 2003: 2), and Le Grand arguing that in general, the choice-andcompetition model for delivering public services is indeed an effective instrument for improving the quality, efficiency, responsiveness and equity of those services - especially when compared with the alternatives' (2007a: 95 ). Although driven by neo-liberal welfare reform, the discourse of choice also has its roots in user empowerment, particularly in responses to failures of the welfare state to respond effectively and responsively to user need. With regards to a growing cohort of ageing service users across different welfare regimes, the exercise of 'choice' within welfare has an international significance.

Much of the rhetoric around the mechanisms of increasing choice relies on assumptions about agency. We would argue that many of the current ideas about the transformation of the UK welfare state to accommodate the growing numbers of older people are based on beliefs about the baby-boomer generation - that they will make demands and behave as modern consumers (Byers 20o6). But what about those older than the baby boomers, who will be the main users of welfare services for at least the next decade? Mannheim (1952) can be said to have prompted the sociological use of the idea of generation which is of relevance here, in conjunction with Pierre Bourdieu's (1990) insights into the relationship between agency, welfare interactions, choice and consumerism, particularly the concepts of habitus, field and capital. Bourdieu's (1990) concept of habitus can be defined as a system of individual dispositions acquired over the lifecourse which both reflect and are constitutive of particular social realities. By using this term, Bourdieu hoped to integrate both structure and agency in social scientific analyses, giving no particular priority to either level. Drawing on both Mannheim (1952) and Bourdieu's (1990) analysis of the importance of culture and structure on generation, Gilleard (2004: 114 ) suggests the idea of a 'generational habitus' defined as 'dispositions that generate and structure individual practices which emerge and are characterised by the forces operating in a particular generational field'. A clear advantage of such an approach is that it enables a focus on both structure and agency, 'recognising the importance of the material conditions that have structured shifts in the systems of symbolic exchange mediating such patterns of engagement' (Gilleard 2004: 115). Greener (2002: 703) analyses the concept of agency in relation to welfare and points out that the, 'underlying assumptions that policy makers have about agency are crucial for the effectiveness of policy'. Current changes in the context of welfare provision, such as greater targeting and means testing, or more 
individualisation, require a more consumerist mode of behaviour, a different mode of agency.

Developing Peillon (1998) and Greener's (2002) application of Bourdieu's analysis of welfare interactions to the case of older people, habitus is a central element and constitutes the principle according to which practices are generated. The idea of a generational 'welfare habitus' proposes that the collective forces of structure and individual practice in relation to welfare accumulate over a lifetime and influence the ways in which people interact with the welfare system in later life (Moffatt and Higgs 2007). Thus, the 'welfare habitus' encompasses the idea that the particular social, economic and political circumstances which have prevailed at various points since the emergence of mass consumer society in the $195^{\mathrm{os}}$ and which have created the opportunities for a generational habitus built around lifestyle and choice have their corollary in approaches to and expectations of the welfare state and public services. Those now over state retirement age may have most reliance on transformed public services, yet not so readily adapt the habits of a lifetime. In a similar vein, Baldock (2003: 68) suggests that, 'the internalization of [welfare] norms is a long cultural process', and we suggest that the welfare habitus is one that reflects a set of experiences and cultural understandings more akin to social security and citizenship than 'Third Way' social policy with its emphasis on individualism and contractualism (Harris 1999). This analysis would suggest that older people born prior to the baby-boom years $\left(1945^{-60}\right)$ are required to operate within a new field of choice and consumerism for which many are unprepared. We assess these theoretical standpoints against available evidence on the uptake of a more consumerist mode of service provision in a later section. Before doing so, we portray a relatively new dimension of the UK public service landscape that has relevance to older people-devolution.

\section{Devolution and policy divergence in Scotland, Wales and England}

Kingdon (2002) asserts that the essentially 'messy' nature of policy development in complex systems means that the role of ideas whose 'time has come' is increasingly important. The dominance of the 'choice' discourse in social policy directed at older people across different welfare regimes is an example of this (Clarke et al. 2007). Dolowitz and March (2000) argue that where policy makers are grappling with similar issues and pressures in complex systems, there is a tendency for policy transfer to take place across state, regional and local government levels. At the same time, welfare systems with a high degree of decentralisation (e.g. federal systems in Canada and Australia) have developed devolved responsibilities for older people's 
welfare that serve a dual purpose. Firstly, an emphasis on cost containment is prevalent where services are developed to be responsive to local needs and front-line providers are responsible for rationing access to resources. Secondly, devolved governance systems offer the opportunity for policy transfer to take place across localities and regions and a degree of organisational learning to take place independently of path dependency and service restraints (Keating 2003). Examining the role of choice in older people's services across devolved governments therefore gives us the opportunity to explore some of the tensions between policy divergence and transfer.

Political devolution came about in 1999 when the UK Parliament transferred a range of powers to national parliaments or assemblies, at which time the Scottish Parliament, the National Assembly for Wales and the Northern Ireland Assembly were established. A number of areas are 'reserved' to the UK Parliament in Westminster, London, and these include defence, foreign policy and social security. Devolution has been dominated by the major social service areas of health, social care, education and housing (Birrell 2009). The extent of devolution and power arrangements are different in Scotland, Wales and Northern Ireland, reflecting their history and administrative structures. Although there is 'asymmetry' in the devolution settlement which has transferred more political power to Scotland than Wales or Northern Ireland (Woods 2002), each nation has pursued policies in health, social care and education that are distinctive from England. Although in the UK the main powers to promote age equality and tackle poverty in later life sit with the UK Parliament in Westminster, for the first time since the inception of the British welfare state, there are now formal differences in entitlement for older people as a result of devolution.

It is now over ten years since devolution, and it is timely to consider its impact on policy and practice towards older people. Academic studies have predominantly focused on divergence-convergence, and this has usually involved comparisons between one of the devolved nations and England (Birrell 2009). In this paper, we will focus predominantly on Scotland, Wales and England in terms of policies that are relevant to older people. The road to devolution and the establishment of the Northern Ireland Assembly has been subject to considerable political disruption and has only been fully operational since May 2007. For this reason we do not include Northern Ireland in our analysis.

Political devolution impacts on substantial areas of social policy including health, education and social care (McCormick, McDowell and Harris 2009). The populations of Scotland and Wales have poorer levels of health than England, higher death rates, lower levels of life expectancy and more people with long-term illness, as well as higher levels of per capita spending on 
health (Pollock 1999; Stewart 2004; Birrell 2oog). However, Scotland, Wales and England all have deep-seated social and spatial inequalities, although Scotland tends to stands out with its particularly poor and longstanding record of ill-health and premature mortality which currently shows few signs of improvement (Shaw, Davey-Smith and Dorling 2005). It has been argued that prior to devolution, there was a more distinctive Scottish public-sector ethos not manifest to the same degree in England (Greer 2003; Stewart 2004). Wales has to some extent been perceived as an adjunct to England largely through historical circumstances. Simmons, Powell and Greener (2009) point out that considerable attention has been given to political devolution after 1999, but that much less is known about the impact of devolution on health and welfare. Moreover, it would be a mistake to assume that health and welfare services were uniform across Scotland, Wales and England before 1998, and that all differences observed now are a result of devolution, although relatively little is known about many aspects of health and welfare prior to political devolution. What we do know is that within health care there were perhaps fewer differences between England and Wales, but Scotland and Wales had much smaller markets for private health care than England (Pollock 1999). The radical programme of reform within the National Health Service (NHS) in England (Milburn 2001) encouraging individual patient choice alongside the expansion of the private sector has not been replicated in Scotland or Wales since devolution (Woods 2002). The reforms proposed in the coalition government's Health and Social Care Bill 2010-11 (House of Commons 2011 ) will set England further adrift from Scotland and Wales, since, if adopted, the changes amount to, 'the abolition of the English NHS as a universal, comprehensive, publicly accountable, tax funded service, free at the point of delivery' (Pollock and Price 201 1: 803). Several commentators have attested to the existence of a stronger 'welfare landscape' in Scotland (Sullivan 2002; Wood 2002; Greer 2003; Stewart 2004). Sullivan (2002) and Tannahill (2005) assert that the post-devolution organisation of Scotland's NHS services reflects Scotland's 'communitarian' values and demonstrates the continuation of an existing characteristic of Scottish welfare. Mooney and Poole (2004) are more sceptical of this influence on social policy in post-devolution Scotland, arguing that in key areas of policy, such as welfare to work, New Labour policies in Scotland are identical to those in the UK Parliament. Interestingly, Sullivan (2002) points out that Welsh health policy since devolution marks the most radical departure from the emphasis on consumerism and choice in England, reflecting Old Labour traditions.

Scotland, Wales and England have their own distinct strategies on ageing and older people, the most recent being: Building a Society for All Ages (Department for Work and Pensions 2009) (England); All Our Futures 
(Scottish Executive 2007) (Scotland); and The Strategy for Older People (Welsh Assembly Government 20o8) (Wales). Overall, there are few major differences in policy objectives from what is a relatively short period of devolved policy making (McCormick, McDowell and Harris 2009) and the number of totally unique policies are not extensive (Birrell 2009). Differences of note are that Scotland is the only nation without a named older people's 'champion', the other nations having some sort of older person's advocate. The Commissioner for Older People in Wales is perhaps the most advanced advocate model in the UK. The Welsh Commissioner is independent from government and holds the Welsh government, local government and the NHS to account and is also responsible for 40 per cent of the total strategy budget. In an analysis of devolution and older age in the UK, McCormick, McDowell and Harris (2009) argue that policy variations are 'mostly modest', but that implementation may vary substantially, particularly given that there is considerable variation in the methods of scrutiny in the devolved nations.

The policy that has received most attention since devolution has been the right to free personal care for older people in Scotland, a decision made by a Labour administration (Ferguson 2005). Since the shift in political power to the Scottish National Party in May 2007, this policy remains unchanged, and is popular throughout Scotland. However, the current and projected cuts in public expenditure have called this policy into question, and it remains to be seen whether, as a universal right, it will survive cutbacks (Puttick 2010). Analysis of the impact of free personal care for older people in Scotland indicates that it has improved equity, particularly for women and those on lower incomes (Bell and Bowes 20o6). However, there was widespread confusion among older people in Scotland about the care system as well as considerable regional variation. The same legislation did much to enshrine rights of informal carers; those in Scotland are not charged for their needs, while informal carers in Wales and England may be charged for any service received (Cavaye 2006).

Bell (2010: 34) argues in relation to long-term care that, 'devolution has made a system that the public, politicians and clients found difficult to comprehend even more complex'. This is partly due to the fact that social care is under the jurisdiction of the devolved administrations, but the related social security system that includes payments to compensate for care needs is reserved to the UK Parliament. ${ }^{1}$ The funding of social care for older people continues to be a major issue within UK social policy and politics, and highlights the potential for devolution to enable policy experimentation and divergence, with considerable implications for citizens.

There has been almost no research into the impact of policy divergence resulting from devolution across Scotland, Wales and England and therefore 
little opportunity to learn from the various policies (Bell 2010). On the demand side, there is much greater variation within the nation states than between them. Analysis of local authority rates of Attendance Allowance ${ }^{2}$ uptake shows that rates vary from 4 to 37 per cent (Bell 2010). In terms of providing care, there has been an overall downward trend across all parts of the UK, reflecting a shift away from friends and family providing care to reliance on cash benefits. Around 11 per cent of adults provided care to other adults in $2007-08$, but there is no evidence of diverging trends in unpaid care provision that might be associated with differences in long-term care policy across the UK (Bell 2010).

Since devolution, two major factors have influenced the provision of longterm care, namely the increased role of the private sector and the implementation of consumer choice. Prior to devolution, England had a more developed role for the private sector and this has increased considerably (from $5 \%$ in 1993 to $81 \%$ in 2009 for publicly funded home care) but is much less developed within the devolved nations -36 per cent in Wales and 53 per cent in Scotland (Bell 2010: 21 ). We explore the notion of consumer choice within social care in more detail below, but to set some background with respect to devolution, more people in England receive payments that allow them to exercise 'choice' in relation to their care needs than in the devolved nations. England, therefore, not only has much greater involvement of the private sector in long-term care, but also more people taking up personal budgets 3 to pay for their care. Ideological differences explain the slower rate of advance of the private sector to some extent. Evidence would also suggest that there has been local resistance to the personalisation of care (particularly in Scotland) from local politicians, front-line staff and managers (Priestley et al. 2006), perhaps driven by a greater commitment to collectivism and loyalty to the welfare state in Scotland (Keating 2003). What is not yet possible to answer adequately is whether and how devolution has benefited those in receipt of care, although it would appear that where and how individuals age will affect the type of services they receive and whether and how they are expected to pay for them. McCormick, McDowell and Harris (2009: $3^{1}$ ) point out that a considerable amount is known about the objectives of the various devolved policies towards older people, but not enough about their impact, and that it is still too early to say what difference, if any, devolution has made to outcomes for older people as a whole. Unfortunately, the mechanisms that enable the devolved nations to share good practice and hence, the opportunities to learn from the various divergent policies, have not been adequately exercised.

Social care is perhaps the most significant example of a shift in social citizenship rights hitherto within a unitary welfare state with assumptions of broadly equivalent services free at the point of use (Woods 2002). 


\section{Suzanne Moffatt et al.}

Devolution raises fundamental questions about entitlements, citizenship and social justice as the 'significance of place and more broadly nation in the meaning of welfare is re-organised and re-emphasised' (Williams and Mooney 2008: $5^{\mathrm{OO}}$ ). The broad consensus at present is that the years since devolution have not produced a fundamental divergence in the quality of social citizenship (Birrell 2009). The next section explores in more detail the characteristics of choice and consumerism in public services and how this might relate to older people.

\section{Choice and consumerism in public services}

The concept of choice in social policy has different political and ideological underpinnings and some of these contradictions are played out in the different national policy contexts of Scotland, Wales and England. On the one hand, choice is linked inextricably with neo-liberal and new managerialist movements in public policy which have sought to present it as a 'good thing' in its own right as a way to achieve more responsive, effective and efficient public services (Clarke et al. 2007). In this conception choice is linked with consumerist developments such as the introduction of markets and quasi-markets in public services, particularly health, housing and social care services (Greener and Powell 2008). The various approaches to choice in Scotland, Wales and England can be linked to both the differing levels of devolved policy making in the respective public policy areas, and to the different political and ideological commitment to the overarching neoliberal and new-managerialist policy framework. For example, 'patient choice' within the English context is encapsulated within several policy directives (e.g. Department of Health 2003a, 2006, 2007a), but is largely absent within the Scottish and Welsh equivalents, despite all three health systems facing the same cost containment and equity pressures (Greer 2004). On the other hand, choice is also linked to increasing 'bottom-up' demands from service users for more responsive, user-centred services, as a rejection of the perceived paternalism and inefficiency of monolithic state providers and the fragmentation of non-state provision of public services. Moves to increase choice over providers in areas such as health, social care and education have been linked to increasingly politicised and consumerist-oriented user movements (Fotaki 2oog). Correspondingly, the rhetoric and reality of 'choice' in public services in Scotland, Wales and England is also related to how powerful a 'voice' patient, user and consumer groups have within the differing political systems (Greer 2007). As we shall see below, the differential rates of take-up in personalisation schemes in social care across the three national contexts are a clear example of this 
divergence in both top-down and bottom-up policy making and implementation.

Although all public services have undergone some degree of change towards increasing consumerism, mechanisms to facilitate consumer-type choices have developed most strongly within adult social care (Glendinning 2009) and to a lesser extent within health care (Powell and Greener 2009). It is now widely accepted that there has been a shift from the post-war consensus built up around the Keynesian welfare state towards a more consumer-led, marketised welfare state, but less clear cut are questions around who constitutes the consumer(s) of these services, and how the mechanisms of consumerism operate. The 'consumer as chooser' is the perspective that has dominated academic writing and policy making, developed out of the classic economic ideal of consumer as 'utility maximiser' (Simmons and Powell 2009). In this framework, based on the ability of the consumer to shop around and obtain information about the various services on offer, they can 'exit' a poorer quality or less suitable service for another, and in doing so, drive up standards, and make services more responsive. It is this model of the consumer that dominated the New Labour policy agenda and one, as we shall point out, that is contested. A more nuanced, contexualised and differentiated understanding of 'the consumer' has developed out of work on health, social care, crime and education which highlights other important dimensions of the concept of consumer that have received much less attention (Simmons, Powell and Greener 2009). These include the consumer as citizen, communicator, activist and rebel; whereby 'voice' constitutes the operational mechanism. Older people's voices are now more prominent in many settings including health, social care, research and advocacy, or are represented by large national charities such as Age UK and the Alzheimer's Society. However, engagement in this way raises issues of representativeness and whether those with a voice can be said to represent those without one, and as Le Grand ( 20076 : 209) points out, 'voice does not deliver equity'. Moreover, existing evidence suggests that users of public services do not view themselves as consumers or citizens, but as members of the public, members of the local community, service users or patients (health care). Increasingly, evidence shows that no single model suits everyone and that there are a significant number of people who 'retain more passive relationships with public services-particularly in professionalized contexts ... suggesting that some consumers will benefit less than others from greater "choice" (Simmons and Powell 2009: 264).

We turn now to focus on the consumer and choice agenda as it might relate to older people. In doing so, it is necessary to distinguish between two elements. The first is engagement with consumer society per se. It is no longer the case that later life can be defined as a 'period dominated by poverty and 
exclusion from society' (Jones et al. 2008: 115). Analysis of data from the Family Expenditure Survey (FES) from the last 40 years of the 2oth century show that the overall trend among older people is towards increased ownership of and expenditure on key consumer goods. Within this overall trend, there is, unsurprisingly, differential engagement with consumption depending on income, wealth, social location, cohort and generation (Jones et al. 2008). The second element is older people's engagement with the consumer agenda as it is applied to public services - particularly welfare services. Older people are the greatest 'consumers' of health and social care services. It is therefore worth examining the extent to which elements of these services have been subject to consumerist mechanisms and how this has impacted on older people using such public services. Most importantly, questions of equity emerge as major considerations following the introduction of choice mechanisms into public services. There is, at present, little empirical evidence to show whether these mechanisms reduce or exacerbate existing inequalities (Simmons, Powell and Greener 2009), although critics would argue that providing more choice increases inequity because the better off are more able to exercise choice when it is offered (Fotaki 2009; Hunter 2009). It is necessary, therefore, that consumer mechanisms in public services should be subject to 'empirical examination of the type, level and distribution of inequity' (Powell et al. 2009: 2). To this research agenda we would add the potential of divergent post-devolution policies to address later-life inequalities.

\section{Has consumerism and choice in public services been helped or hindered by devolution?}

Health can claim to be the area of social policy where devolution has had the greatest impact and it is suggested that 'we now need to talk about the four health systems of the United Kingdom rather than a unitary NHS' (Jervis 2008). The National Service Framework (NSF) for older people in England (Department of Health $2003 b$ ) was an important policy concerning a series of standards for services that patients and patient groups could expect and was based on the ideas of 'voice' and 'choice'. The eight standards included preventing age discrimination within health care, reducing disability and the need for long-term care, increasing the likelihood that older people would maintain independence and enhancing wellbeing. A Welsh NSF followed in 2006, but a similar framework was not implemented in Scotland. Evaluating the English NSF, Manthorpe et al. (2007) concluded that older people did not perceive improvements as the result of the NSF, but did identify some improvements in health-care systems. Arguably as a result of the NSF for 
older people, there is now a much more prominent role for user and carer ('consumer') representatives within health care, indicating that older people may have greater 'voice', although there have been no comparisons made between older people's experiences of health care in Wales, where this initiative was implemented later or in Scotland where it was not implemented at all.

Within the long-term and social care sectors there has been nothing short of a revolution in care provision from NHS and local authority to the independent and voluntary sector, although as we have pointed out, this has occurred much more in England than Scotland or Wales. Alongside has been the development of the 'consumer' 'personalisation' agenda within social care which over the past decade has been extended to include older people. A key element is the system of Direct Payments that enables disabled and older people to apply for payments in lieu of directly provided services (the level of which are set according to a needs assessment). These payments are usually used to directly employ formal care workers or purchase care from not-for-profit care agencies (Rummery 2009). Direct Payments enable older people to buy services that they need and Individualised Budgets extend the existing scheme to cover a larger number of possibilities not solely limited to social care (Spandler 2004). The personalisation agenda is designed to give people choice about how they manage their care. There is considerable evidence that disabled groups have welcomed Direct Payments and Individual Budgets and that they have shown improved outcomes (Rummery 2006). As a result, these were extended to older people in England (2000), Scotland (2004) and Wales (2005). One small-scale study showed older people in England regarded Direct Payments positively (Clark, Gough and Macfarlane 2004). To begin with, overall take-up among older people was low; in England less than 1 per cent (Age Concern England 2006), in Scotland 0.07 per cent (Scottish Executive 2006) and in Wales 0.55 per cent (Social Interface 2007). Uptake data are only available by age group in England which shows an increase in take-up among the 65-plus age group to 3 per cent (of 661, ooo older people receiving community services in March 2008; Commission for Social Care Inspection 2009). Overall, the take-up of this method of receiving social care services has remained low and highly variable across different local authorities, regions and countries within the UK (Glendinning 2009). This has been explained in two ways - the reluctance of local authorities to promote Direct Payments and bureaucratic barriers they place in the way of take-up; and reluctance on the part of older people to take them up due to the real or perceived burdens they bring (Commission for Social Care Inspection 2009). Even if the reason for low take-up was primarily as a result of institutional reluctance, it might be expected that user groups would be lobbying for greater implementation 
of Direct Payments, as occurred with the successful lobbying of younger disabled people, but this has not yet been observed. Further evidence about older people's equivocal views about this more consumer-oriented method of receiving care comes from the results of a pilot study of Individual Budgets in England which indicated that older people preferred traditional services and that planning and managing their own support actually lowered their wellbeing (Individual Budgets Evaluation Network 2008). Older people did not appear to want this 'additional burden' and the risks were perceived to outweigh the benefits, yet the policy has been extended to all English local authorities (Department of Health 2007b); a similar scheme was introduced in Scotland in 2007 (Scottish Government 2007).

Existing evidence, of which there is not much, indicates that older people, like the public as a whole, resist the wholesale application of consumerist experiences and expectations towards public services and view choice as highly dependent on context and conditions (Clarke and Newman 2007). As we have pointed out earlier, there has been little attention paid specifically to older people born prior to the baby-boomer generation. The evaluation of Individual Budgets indicates that older people largely rejected this mode of agency, echoing earlier work by Baldock and Ungerson (1994) which demonstrated that obstacles to consumer participation in the care system were related to values and culture accrued over a lifetime as well as lack of money, specialist knowledge and contacts (material, cultural, social and symbolic capital).

There is evidence that older people wish to have high-quality services and greater control over their care, but there is less convincing evidence that they wish to exercise consumerist choices to achieve those aims (Barnes and Walker 1996; Rummery 2002). Le Grand's (1989) work on consumerist mechanisms within welfare services, specifically the exercise of choice, voice and exit, showed how this advantages the well-educated with access to social, political and economic capital and disempowers more vulnerable groups and individuals. Barr, Fenton and Blane (2008: 273) claim that encouraging explicit choice in health care, 'might further improve those with greater voice' and lead to increased inequity. Certainly evidence on take-up of personalised budget care schemes in the UK suggests that it is generally articulate, younger, well-informed disabled people who are disproportionately represented among those who use them (Spandler 2004). The findings to date clearly show that exercising choice clearly benefits some more than others - those best able to benefit from the market by exercising choice, voice and exit (Rummery 2009), and it is unlikely that many older recipients of Individualised Budgets are in an optimal position to do likewise.

We have demonstrated that, to some extent, devolution has delayed and prevented the introduction of consumerist and choice mechanisms within 
public services in Scotland and Wales. With a few exceptions, this is less a consequence of devolution per se, but more a strengthening of existing predevolutionary ideologies and policies. In our final section, we attempt to integrate the perspectives of choice and devolution by exploring whether the more diluted policies within Scotland and Wales might be more successful in reducing later-life inequalities.

\section{Devolution, choice and inequalities}

UK devolution presents new circumstances in which to understand public services, with greater localism and more fragmentation than at any other time since the start of the welfare state. The more localised changes brought about by devolution have resulted in different opportunities for individuals to exercise choice regarding public services in Scotland, Wales and England. We agree that it is too early as yet to detect significant differences in the outcomes of later-life experiences of older citizens in Scotland, Wales and England as a result of devolution (Birrell 20o9; McCormick, McDowell and Harris 2009; Bell 2010). We do, however, suggest policy divergence has already differentiated older people's experiences of public services in these nations. While not ignoring the importance of the, still uniform, level of the UK state pension and means-tested welfare payments, the shift towards increased consumerism and choice within some parts of the UK raises crucial questions about the potential for these policies to reduce or exacerbate inequalities in later life. If increased choice increases inequalities, as argued by Barr, Fenton and Blane (2008) and Hunter (2009), then Scottish and Welsh policies are more likely to promote equality in later life. If, however, increased choice has the potential to reduce inequity (Cooper and Le Grand 2007) then English policies are more likely to have the desired effect. These are important questions, as despite the overall improvement in living standards for older people in the UK (Gilleard et al. 2005 ), there is evidence of widening income inequalities among older people (Bardasi, Jenkins and Rigg 2002). The Institute of Fiscal Studies predicts that the proportion of over $6_{5} \mathrm{~s}$ living in poverty in the UK is set to remain at around one-in-five between 2007-08 and 2017-18 (Brewer et al. 2007). Inequalities in health persist into later life (Chandola et al. 2007), as does the burden of meeting additional direct and indirect costs associated with disability (Argyle 2001). A review of the impact of policies to reduce poverty and social exclusion among older people indicated that these have not yet successfully challenged inequalities which are carried through into old age as a result of social class, gender, ethnicity and disability (Phillipson and Scharf 2004). 
Referring back to our earlier theoretical discussion of older people's interactions with public services, we draw once again on Bourdieu (1990) in considering whether consumer mechanisms are more or less likely to widen inequalities. Bourdieu (1990) considers four types of capital: economic (material wealth); cultural (education, cultural goods); social (connections, social networks, group membership); and symbolic (legitimate possession and exercise of other forms of capital). It goes without saying that the distribution of these forms of capital is unequal and those with the least available 'capital' will have greatest need for state-funded public services as they age (Moffatt and Scambler 20o8). Yet, we already know that many older people fail to actively interact with public services, evidenced by failure to claim full welfare entitlements (Department for Work and Pensions 2004), and the low take-up of Individualised Budgets (Commission for Social Care Inspection 2009). As well as recognising the importance of material conditions, Bourdieu's (1990) analysis of different types of capital offers further explanatory potential of the difficulties that many older people may have in negotiating the new 'landscape' of public services. As others have already suggested, norms and beliefs internalised over a lifetime and developed within particular social, economic and political circumstances influence interactions with state-funded public services, as well as the particular mechanisms that drive service provision (Greener 2002; Baldock 2003; Moffatt and Higgs 2007). In the absence of any evidence to the contrary as yet, we would agree with critics that the most likely outcome for older people is an exacerbation of existing inequalities in public service arenas where choice and consumer mechanisms predominate (Barr, Fenton and Blane 2008; Hunter 2009). Therefore, different policy approaches for older people's services arising out of devolution might be expected to impact differentially on later-life inequalities. Devolution offers an, as yet unexplored, opportunity to judge the impact of these policies.

\section{Conclusions}

In this paper, we have brought together work on devolution and choice in social policy and attempt a tentative exploration of what this changing public service landscape might mean for older citizens, particularly in relation to inequalities. Through a combination of pre-devolution policies and post-devolution policy divergence, the emphasis on choice in public services in England has not been followed to the same extent in either Scotland or Wales. We argue that devolution has hindered the introduction of these mechanisms in public services in Scotland and Wales. It is as yet premature to establish whether this policy divergence translates into better, 
as well as different, public services, and also too early to establish whether there are any measurable differences in outcome. What we can say with confidence is that devolution has led both to the emergence of different policy instruments and to evidence that older 'consumers' of welfare services are engaging with practictioners and services in different ways across the different policy contexts explored in this paper. While political proponents of the consumer agenda use the language of empowerment and take it as read that exercising choice can only be beneficial, individually and for society at large, recent work indicates that parts of the public resist consumerist models of public services and some do not welcome a reduced role for state-provided welfare. We would argue that the evidence we have presented here suggests that for many older people, the prospect of having to become a consumer in these varied contexts is confusing, daunting and disabling (Baldock and Ungerson 1994), and that those operating in a policy context which protects them from the risks of consumerism are likely to experience better outcomes. Furthermore, pursuit of the choice agenda in social policy and practice is linked to a much higher risk of increasing inequalities with regards to access to welfare provision for older people. Surprisingly little work has been undertaken to link older people's experiences and views of public services and to examine whether they, too, construct a 'sceptical distance' from consumerist reforms (Clarke and Newman 2007: 755). The opportunity for a 'naturalist' experiment in policy divergence across the devolved policy contexts of Scotland, England and Wales will, of course, take far longer than a decade to show significant measurable divergence in outcomes for older people, but this paper does offer evidence that the hegemony of choice and consumerism in welfare provision can be resisted, and that some older people will not, to paraphrase D. H. Lawrence, 'go quietly into the night' of consumerism and choice but will 'rage against the dying of the light' of the state provision of welfare. The limits of policy experimentation allowed by devolution indicate that by no means can Scotland and Wales be characterised as being significantly divergent from the UK in terms of welfare regimes: but we would argue that there is still scope for questions of agency and citizenship to be a significant part of the context of policy development and practice for older people even within those limitations. This would indicate that where developed welfare states have allowed a degree of policy devolution, older people may benefit from opportunities to resist the hegemony of choice and consumerism that characterise contemporary welfare provision across different international contexts.

\section{Acknowledgement}

We wish to thank Professor Peter Phillimore for his comments. 


\section{Suzanne Moffatt et al.}

\section{NOTES}

1 There are a number of social security payments that are paid to compensate for care needs. The various benefits and rates are set by the UK Parliament, although take-up rates vary considerably throughout the UK.

2 Attendance Allowance is a non-means-tested state benefit paid to claimants over 65 and is assessed on the basis of their care needs. The number of recipients in May 2009 was 1,585,790 (Corden et al. 2010).

3 Personal budgets for care, known as Direct Payments or Individual Budgets, are local authority payments for people who have been assessed as needing help from social services, and who would like to arrange and pay for their own care and support services instead of receiving them directly from the local authority.

\section{References}

Age Concern England 20o6. Benefits of Direct Payments Revealed. Available online at http://www.ageconcern.org.uk [accessed 6 May 2007].

Appleby, J., Harrison, A. and Devlin, N. 2003. What is the Real Cost of More Patient Choice? King's Fund, London.

Argyle, E. 2001. Poverty, disability and the role of older carers. Disability and Society, 16, $4,5^{8} 5^{-95}$.

Baldock, J. 2003. On being a welfare consumer in a consumer society. Social Policy and Society, 2, 1, 65-71.

Baldock, J. and Ungerson, C. 1994. Becoming Consumers of Community Care: Households Within the Mixed Economy of Welfare. Community Care into Practice Series, Joseph Rowntree Foundation, York, UK, $1-56$.

Bardasi, E., Jenkins, S. and Rigg, J. 2002. Retirement and the income of older people: a British perspective. Ageing $\mathcal{E} \mathcal{F}^{2}$ Society, 22, 2, $131-59$.

Barnes, M. and Walker, A. 1996. Consumerism versus empowerment: a principled approach to the involvement of older service users. Policy and Politics, 24, 4, 375-93.

Barr, D. A., Fenton, L. and Blane, D. 2008. The claim for patient choice and equity. Journal of Medical Ethics, 34, 271-4.

Bell, D. 2010. The Impact of Devolution. Long-term Care Provision in the UK. Joseph Rowntree Foundation, York, UK.

Bell, D. and Bowes, A. 20o6. Financial Care Models in Scotland and the UK. Joseph Rowntree Foundation, York, UK.

Birrell, D. 2009. The Impact of Devolution on Social Policy. Policy Press, Bristol, UK.

Blomqvist, P. 2004. Privatisation of Swedish welfare services. Social Policy and Adminstration, 38, 3, 139-55.

Bourdieu, P. 1990. The Logic of Practice. Polity Press, Cambridge.

Brewer, M., Browne, J., Emmerson, C., Goodman, A., Muriel, A. and Tetlow, G. 2007. Pensioner Poverty Over the Next Decade: What Role for Tax and Benefit Reform? Institute for Fiscal Studies, London.

Byers, S. 2006. A new deal for older people must become a top political priority. The Guardian, 6 September.

Cavaye, J. 20o6. The care of older people. In Mooney, G., Sweeney, T. and Law, A. (eds), Social Care. Health and Welfare in Contemporary Scotland. Kynoch \& Blaney, Paisley, UK, 239-70. 
Chandola, T., Ferrie, J., Sacker, A. and Marmot, M. 2007. Social inequalities in self reported health in early old age: follow-up of prospective cohort study. BMJ Online First. doi:10.1136/bmj.39167.439792.55 [accessed 8 May 2007].

Clark, H., Gough, H. and Macfarlane, A. 2004. 'It Pays Dividends.' Direct Payments and Older People. Policy Press, Bristol, UK.

Clarke, J. and Newman, J. 2007. What's in a name? New Labour's citizen-consumers and the remaking of public services. Cultural Studies, 21, 4/5, 738-57.

Clarke, J., Newman, J., Smith, N., Vidler, E. and Westmarland, L. 2007. Creating Citizen-consumers: Changing Publics and Changing Public Services. Sage, London.

Clasen, J. 1998. Comparative Social Policy. Blackwell, Oxford.

Commission for Social Care Inspection 2009. The State of Social Care in England 2007/ 8. Care Quality Commission, London.

Cooper, Z. and Le Grand, J. 2007. Choice, competition and the political left. Eurohealth, 13, 4, 18-20.

Corden, A., Sainsbury, R., Irvine, A. and Clarke, S. 2010. The Impact of Disability Allowance and Attendance Allowance. Department for Work and Pensions Research Report, No. 649, HMSO, Norwich.

Department for Work and Pensions 2004. Income Related Benefits Estimates of Take-up in 2OOI/2OO2. Office of National Statistics, London.

Department for Work and Pensions 2009. Building a Society for All Ages. Available online at http://webarchive.nationalarchives.gov.uk or http://www.hmg.gov.uk/ buildingasocietyforallages.aspx [accessed 26 July 2010].

Department of Health 2003 a. Building on the Best. Choice, Responsiveness and Equity in the NHS. Department of Health, London.

Department of Health 2003b. The National Service Framework for Older People. The Stationery Office, London.

Department of Health 2006. Our Health, Our Care, Our Say: A New Direction for Community Services. Department of Health, London.

Department of Health 2007a. Next Steps Review: Interim Report. Department of Health, London.

Department of Health 2007 b. Putting People First: A Shared Vision and Commitment to the Transformation of Social Care for Adults in England. Cm6499, Department of Health, London.

Dolowitz, D. and Marsh, D. 20oo. Learning from abroad: the role of policy transfer in contemporary policy-making. Governance, 13, 1, 5-24.

Esping Andersen, G. 1996. Welfare States in Transition. National Adaptations in Global Economies. Sage, London.

Ferguson, I. 2005. Social work and social care in the 'new' Scotland. In Mooney, G. and Scott, G. (eds), Exploring Social Policy in the 'New' Scotland. Policy Press, Bristol, $\mathrm{UK}, 221-38$.

Fotaki, M. 2009. Are all consumers the same? Choice in health, social care and education in England and elsewhere. Public Money and Management, 29, 2, 87-94.

Gilleard, C. 2004. Cohorts and generations in the study of social change. Social Theory $\mathcal{E}$ Health, 2, 106-19.

Gilleard, C. and Higgs, P. 2005. Contexts of Ageing: Class, Cohort and Community. Polity Press, Cambridge.

Gilleard, C., Higgs, P., Hyde, M., Wiggins, R. and Blane, D. 2005. Class, cohort, and consumption: the British experience of the Third Age. Journal of Gerontology, $\mathbf{6 o B}, 6$, $\mathrm{S}_{30} 5^{-10 .}$

Glendinning, C. 2009. The consumer in social care. In Simmons, R., Powell, M. and Greener, I. (eds), The Consumer in Public Services. Choice, Values and Difference. Policy Press, Bristol, UK, 177-96. 


\section{Suzanne Moffatt et al.}

Greener, I. 2002. Agency, social theory and social policy. Critical Social Policy, 22, 4, 688-705.

Greener, I. and Powell, M. 20o8. The evolution of choice policies in UK housing, education and health policy. Journal of Social Policy, 38, 63-81.

Greer, S. 2003. Policy divergence: will it change something in Greenock? In Hazell, R. (ed.), The State of the Nations 2003: The Third Year of Devolution in the United Kingdom. Constitution Unit, University College London, London, 195-214.

Greer, S. 2004. Territorial Politics and Health Policy. Manchester University Press, Manchester, UK.

Greer, S. (ed.) 2007. Devolving Policies, Diverging Values. Nuffield Trust, London.

Greve, B. 2009. Can choice in welfare states be equitable? Social Policy and Adminstration, 43, 6, 543-56.

Harris, J. 1999. State social work and social citizenship in Britain: from clientelism to consumerism. British Journal of Social Work, 29, 6, 91 5-37.

Hill, M. 20o6. Social Policy in the Modern World: A Comparative Text. Blackwell Publishing, Oxford.

Jeffery, C. 2008. The challenge of territorial politics. Policy and Politics, 36, 4, 545-57.

House of Commons 2011. Health and Social Care Bill 2OIO-2OI I. Stationery Office, London.

Hunter, D. J. 2009. The case against choice and competition. Health Economics, Policy and Law, 4, 489-501.

Individual Budgets Evaluation Network 2008. Evaluation of the Individual Budgets Pilot Programme. Final Report, Social Policy Unit, University of York, UK. Available online at www.york.ac.uk/spru [accessed 3 November 2008].

Jervis, P. 2008. Devolution and Health. Nuffield Trust, London.

Jones, I. R., Hyde, M., Victor, C., Wiggins, R. D., Gilleard, C. and Higgs, P. 2008. Ageing in a Consumer Society. From Passive to Active Consumption in Britain. Policy Press, Bristol, UK.

Keating, M. 2003. Social inclusion, devolution and policy divergence. The Political Quarterly, 74, 4, 429-38.

Kingdon, J. 2002. Agendas, Alternatives and Public Policies. Longman, London.

Le Grand, J. 1989. Markets, welfare and equality. In Le Grand, J. and Estrin, S. (eds), Market Socialism. Oxford University Press, Oxford, 1-24.

Le Grand, J. (ed.) 2007a. The Other Invisible Hand: Delivering Public Services Through Choice and Competition. Princeton University Press, Princeton, New Jersey.

Le Grand, J. 2007b. The politics of choice and competition in public services. The Political Quarterly, 78, 2, 207-13.

Mannheim, K. 1952. The problem of generation. In P. Kecskesmeti (ed.), Essays on the Sociology of Knowledge. Routledge and Kegan Paul, London, 28o-322.

Manthorpe, J., Clough, R., Cornes, M., Bright, L., Iliffe, S. and (OPRSI) Older People Researching Social Issues 2007. Four years on: the impact of the National Service Framework for Older People on the experiences, expectations and views of older people. Age and Ageing, 36, 5, 501-7.

McCormick, J., McDowell, E. and Harris, A. 2009. Policies for Peace of Mind? Devolution and Older Age in the UK. Institute for Public Policy Research, London.

Milburn, A. 2001. Shifting the Balance of Power in the NHS. Launch of the NHS Modernisation Agency. Department of Health, London.

Moffatt, S. and Higgs, P. 2007. Charity or entitlement? Generational habitus and the welfare state among older people in North East England. Social Policy and Administration, 41, 5, 449-64.

Moffatt, S. and Scambler, G. 2008. Can welfare-rights advice targeted at older people reduce social exclusion? Ageing E् Society, 28, 6, 875-99. 
Mooney, G. and Poole, L. 2004. 'A land of milk and honey?' Social policy in Scotland after devolution. Critical Social Policy, 24, 4, 458-83.

Peillon, M. 1998. Bourdieu's field and the sociology of welfare. Journal Social Policy, 27, 2, $213^{-29}$.

Phillipson, C. 2002. Ageism and globalisation: citizenship and social rights in transnational settings. In Andersson, L. (ed.), Cultural Gerontology. Auburn House, Westport, Connecticut, $45^{-} 5^{8}$.

Phillipson, C. and Scharf, T. 2004. The Impact of Government Policy on Social Exclusion Among Older People. Social Exclusion Unit, London.

Pollock, A. M. 1999. Devolution and health: challenges for Scotland and Wales. British Medical Journal, 318, $1195^{-8 .}$

Pollock, A. M. and Price, D. 2011 . How the Secretary of State for Health proposes to abolish the NHS in England. British Medical Journal, 342, 800-3.

Powell, M., Doheny, S., Greener, I. and Mills, N. 2009. Introduction: managing the 'unmanageable consumer'. In Simmons, R., Powell, M. and Greener, I. (eds), The Consumer in Public Services. Choice, Values and Difference. Policy Press, Bristol, UK, $1-17$.

Priestley, M., Jolly, D., Pearson, C., Riddell, S., Barnes, C. and Mercer, G. 2007. Direct payments and disabled people in the UK: supply, demand and devolution. British Journal of Social Work, 37, $1189-204$.

Puttick, H. 2010. What now for free personal care? Herald Scotland, 30 July. Available online at http://www.heraldscotland.com/news/health/what-now-forfree-personal-care-1.1034147 [accessed 30 July 2010].

Rummery, K. 2002. Disability, Citizenship and Community Care: A Case for Welfare Rights? Ashgate, Aldershot, UK.

Rummery, K. 2006. Disabled citizens and social exclusion: the role of direct payments. Policy and Politics, 34, 4, 633-5o.

Rummery, K. 2009. A comparative discussion of the gendered implications of cashfor-care schemes: markets, independence and social citizenship in crisis? Social Policy and Administration, 43, 6, 634-48.

Scottish Executive 2006. Direct Payments Scotland 2006. Available online at http:// www.scotland.gov.uk/Publications/2006/og/25160444/13 [accessed 6 May 2008].

Scottish Executive 2007. All Our Futures. Available online at www.scotland.gov.uk/ publications/2007 [accessed 23 July 2010].

Scottish Government 2007. National Guidance on Self Directed Support. Available online at http://www.scotland.gov.uk/Publications/2007/07/04093127/5 [accessed 2 March 2009].

Shaw, M., Davey-Smith, G. and Dorling, D. 2005. Health inequalities and New Labour: how the promises compare with real progress. British Medical Journal, 330, 1016-21.

Simmons, R. and Powell, M. 2009. Conclusion: the consumer in public services. In Simmons, R., Powell, M. and Greener, I. (eds), The Consumer in Public Services. Choice, Values and Difference. Policy Press, Bristol, UK, 255-79.

Simmons, R., Powell, M. and Greener, I. (eds) 2009. The Consumer in Public Services. Choice, Values and Difference. Policy Press, Bristol, UK.

Social Interface 2007. A Survey on the Implementation of the Current Direct Payments Scheme in Wales. Available online at http://wales.gov.uk/dhss/publications/ socialcare/reports/directpayments/surveye.pdf? 1 ang=en [accessed 21 October 2008].

Spandler, H. 2004. Friend or foe? Towards a critical assessment of direct payments. Critical Social Policy, 24, 2, 187-209. 


\section{$74^{6}$ Suzanne Moffatt et al.}

Stewart, J. 2004. Taking Stock. Scottish Social Welfare After Devolution. Policy Press, Bristol, UK.

Sullivan, M. 2002. Health policy: differentiation and devolution. In Adams, J. and Robinson, P. (eds), Devolution in Practice. Public Policy Differences in the UK. IPPR/ESRC, London, 6o-6.

Tannahill, C. 2005. Health and health policy. In Mooney, G. and Scott, G. (eds), Exploring Social Policy in the 'New' Scotland. Policy Press, Bristol, UK, 199-220.

Taylor-Gooby, P. (ed.) 200o. Risk, Trust and Welfare. Macmillan, Basingstoke, UK.

Taylor-Gooby, P. (ed.) 2001. Welfare States Under Pressure. Sage, London.

Welsh Assembly Government 2008. The Strategy for Older People in Wales, 2008-13. Available online at http://wales.gov.uk/topics/olderpeople/publications/ strategy2008-2013/?lang=en [accessed 16 May 2009].

Williams, C. and Mooney, G. 2008. Decentring social policy? Devolution and the discipline of social policy: a commentary. Journal of Social Policy, 37, 3, 489-507.

Woods, K. J. 2002. Health policy and the NHS in the UK 1997-2002. In Adams, J. and Robinson, P. (eds), Devolution in Practice. Public Policy Differences in the UK. IPPR/ESRC, London, $25^{-5}$.

Accepted 27 April 20 I I; first published online zo June 20 I I

Address for correspondence:

Suzanne Moffatt, Institute of Health \& Society, Newcastle University,

Baddiley-Clarke Building, Richardson Road,

Newcastle upon Tyne NE2 4AX, UK.

E-mail: s.m.moffatt@ncl.ac.uk 